\title{
Comparison of absolute neutrophil to CD4 lymphocyte values as a marker of immunosuppression in cancer patients on cytotoxic chemotherapy
}

\author{
Madu Anazoeze ${ }^{1,2}$, Ocheni Sunday ${ }^{1}$, Ibegbulam Obike ${ }^{3}$, Chukwura Awele ${ }^{3}$, Madu Kenechi ${ }^{4}$
}

1. University of Nigeria, Haematology \& Immunology

2. University of Nigeria Teaching Hospital, Haenatology \& Immunology

3. University of Nigeria Teaching Hospital, Enugu, Haematology

4. National Orthopaedic Hospital, Orthopaedics

\begin{abstract}
Background: The absolute neutrophil count (ANC) is currently used to assess immune status of patients on cytotoxic therapy. The CD4 lymphocytes have also been shown to be of importance in protection against opportunistic infections. In people of African descent a low baseline ANC has been recorded and the currently accepted neutropaenic threshold may not be appropriate.

Objective: This study was aimed at comparing the change in ANC to CD4 lymphocyte count in adult cancer patients following chemotherapy.

Patients and methods: Eighty chemotherapy-naive patients with various malignancies had their ANC and CD4 lymphocyte counts done at days 0 and 12 of the first cycle of various chemotherapeutic regimens. The paired sample t-test was done to assess the significance between these values. Socio-demographic data was obtained using questionnaires.

Results: ANC and CD4 pre-chemotherapy differed significantly from their post-chemotherapy values $(\mathrm{p}=0.001)$ for both parameters). The CD4 count showed significant reduction in patients with Non-Hodgkin's lymphoma ( $\mathrm{p}=0.043)$, colorectal carcinoma $(\mathrm{p}=0.037)$ and other malignancies $(\mathrm{p}=0.030)$, while the ANC did not. Patients who had received COPP for Hodgkin's lymphoma also had significant CD4 depletion $(\mathrm{p}=0.037)$.

Conclusion: The CD4 lymphocyte count may be a more suitable parameter than ANC, for monitoring immuno-depletion in cancer patients on cytotoxic chemotherapy. Further studies are required to validate these findings, especially in the Negroid population.
\end{abstract}

Keywords: cancer, chemotherapy, immunosuppression, absolute neutrophil count, CD4 lymphocytes

DOI: http://dx.doi.org/10.4314/ahs.v15i2.34

\section{Introduction}

Cytotoxic chemotherapeutic agents are widely known to cause immunosuppression, the extent of which is routinely ascertained by the absolute neutrophil count (ANC). This blood parameter has been proven to relate positively with the probability of developing infections. ${ }^{1}$ However other blood parameters, like CD4 lymphocyte count has also been proven to positively correlate with the tendency to develop opportunistic and life threatening infections. Some studies in cancer patients on chemotherapy have shown that those that develop marked CD4 lymphopaenia $(<450$ cells $/ \mu \mathrm{L})$

\section{Corresponding author: \\ Madu Anazoeze \\ University of Nigeria, \\ Haematology \& Immunology \\ Email: anazoeze@yahoo.com}

have increased mortality irrespective of their absolute neutrophil count. ${ }^{2,3}$ Normal reference value for CD4+T lymphocyte count in the Caucasian population is 400 - 1500 cells $/ \mu \mathrm{L}$, while a mean absolute CD4 count of $665.6 \pm 246.8$ and $95 \%$ confidence interval (C.I) 588.7 - 742.5 cells $/ \mu \mathrm{L}$ were obtained in a Tanzanian study of which majority were blacks ${ }^{4}$ However studies done in Nigeria reported a mean CD4+T lymphocyte count of 830 cells $/ \mu \mathrm{L}$, with a range of $514-1207$ cells $/ \mu 1$, in healthy adult. ${ }^{5}$

Several studies have shown that individuals of African descent have lower total white cell and ANC compared to Caucasians. ${ }^{6}$ The accepted neutropaenic threshold of $1.5 \times 10^{9} / \mathrm{L}$ is therefore obviously not appropriate for people of negroid descent whose lower reference limit is ANC $1.3 \times 10^{9} / \mathrm{L} .{ }^{6,7}$ Neutropenia remains the most common predisposing factor to infections in cancer patients. ${ }^{1,8,9}$ The accepted definition of neutropenia is an absolute neutrophil count $\leq 1.5 \times 10^{9} / \mathrm{L},{ }^{8}$ though in our 
environment with observed lower absolute neutrophil analyzer. The socio- demographic data of the patients counts, a value of $1.2 \times 10^{9} / \mathrm{L}$ may be considered, be- was assessed from a questionnaire. Ethical approval was ing the lower limit of our reference range. Therefore obtained from the UNTH health research and ethics the use of a different or an additional parameter maybe review board.

required to actually discern those who are actually immune-suppressed in this group.

Data obtained in this study was analyzed using statistical package for social sciences (SPSS) 17.0; frequency disThis study therefore aims to examine the changes that tribution data was generated for the different variable occur in absolute neutrophil and CD4 lymphocyte responses and displayed as tables and figures. Kruskcount in cancer patients due to disease and or due to er-Wallis normality test was carried out prior to analysis chemotherapy. It will also try to compare the changes and normal distribution was observed in patients age, in these parameters for the different types of cancer as $\mathrm{ANC}$ and $\mathrm{CD} 4$ counts. Inferential analysis was done well as various chemotherapeutic regimens, and possi- using the Paired sample $t$-Test and significant $p$ value bly detect the most immunotoxic combinations.

\section{Methods}

was set at $\mathrm{P}<0.05$, with a $95 \%$ confidence interval.

\section{Hypothesis}

This study hypothesizes that CD4 lymphocyte count is of Nigeria teaching hospital (UNTH) Enugu from a more sensitive marker of immunosuppression due to January to December 2007, was calculated to be 0.052 , cytotoxic chemotherapy, than ANC which is being rouusing data obtained from the hospital cancer registry to tinely used. obtain a sample size of 76 (approximated to 80). This was a prospective analysis of eighty adult cancer pa- Results

tients who were assessed in a cross-sectional manner. The mean ANC pre-and post-chemotherapy were The patients had histologically diagnosed malignan- $3.7 \pm 2.2 \times 10^{9} / \mathrm{L}$ and $2.5 \pm 1.6 \times 10^{9} / \mathrm{L}(\mathrm{p}=0.01)$. The mean cies, and were treated with cytotoxic chemotherapeu- CD4 lymphocyte count obtained pre-and post-chemotic agents. They were recruited in a non-randomized therapy were $594 \pm 357$ cells $/ \mu \mathrm{L}$ and $412 \pm 224$ cells $/ \mu \mathrm{L}$ consecutive sampling pattern. Patients, who had been $(\mathrm{p}=0.01)$. There were significant differences in both the exposed to any form of cytotoxic therapy or had been ANC and CD4 lymphocyte counts after chemotherapy diagnosed with any infection, were excluded from the compared to the pre-chemotherapy values.

study.CD4 positive lymphocyte count and absolute neu- The mean pre-chemotherapy ANC for males was $3.8 \pm$ trophil count was carried out on all respondents who $2.3 \times 10^{9} / \mathrm{L}$ and $3.7 \pm 2.1 \times 10^{9} / \mathrm{L}$ for females, while gave informed consent, on days 0 and 12 of the first the mean pre-chemotherapy CD4 lymphocyte coun cycle. Day 12 was chosen because this was the known was $534 \pm 326$ cells/ $\mu \mathrm{L}$ for males and $625 \pm 371$ cells/ neutrophil nadir for most cytotoxic chemotherapeutic $\mu \mathrm{L}$ for females. The mean post-chemotherapy ANC for gents. The CD4 lymphocyte count was obtained using males was $2.7 \pm 2.1 \times 10^{9} / \mathrm{L}$ and $2.4 \pm 1.3 \times 10^{9} / \mathrm{L}$ fo an automated Partec Cyflow ${ }^{\circledR} 2000$ CD4 cell counter, females, while their CD4 counts were $364 \pm 175$ cells/ while the absolute leucocyte count was obtained using $\mu \mathrm{L}$ for males and $436 \pm 243$ cells $/ \mu \mathrm{L}$ for females, post an automated 5-part differential Mythic 22 haematology -chemotherapy.
Table 1: Mean Values of ANC and CD4 Counts Recorded in Different Malignancies Pre- and

Post- Chemotherapy

\begin{tabular}{|c|c|c|c|c|c|}
\hline Diagnosis & $\begin{array}{l}\text { Freq } \\
(\mathrm{N})\end{array}$ & Parameter & Day 0 \pm STD & Day $12 \pm$ STD & t- Test ( $p$ value) \\
\hline \multirow[t]{2}{*}{ 1.Ca Breast } & \multirow[t]{2}{*}{36} & ANC (x $\left.10^{9} / \mathrm{L}\right)$ & $3.577 \pm 2.340$ & $2.326 \pm 1.500$ & $3.436(\mathrm{p}<0.01)^{*}$ \\
\hline & & CD4 (cells $/ \mu \mathrm{L})$ & $612.97 \pm 329.17$ & $428.06 \pm 239.17$ & $5.782(\mathrm{p}<0.001)^{*}$ \\
\hline \multirow[t]{2}{*}{ 2.NHL } & \multirow[t]{2}{*}{8} & $\operatorname{ANC}\left(\times 10^{9} / \mathrm{L}\right)$ & $3.650 \pm 2.646$ & $2.088 \pm 0.640$ & $2.045(\mathrm{p}=0.08)$ \\
\hline & & CD4 (cells / $\mu \mathrm{L}$ ) & $642.00 \pm 261.19$ & $513.50 \pm 272.51$ & $2.460(p=0.04)^{*}$ \\
\hline \multirow{2}{*}{$\begin{array}{l}\text { 3.Hodgkin's } \\
\text { Lymphoma }\end{array}$} & \multirow[t]{2}{*}{13} & ANC (x 109/L) & $3.700 \pm 2.357$ & $2.729 \pm 2.729$ & $1.359(\mathrm{p}=0.20)$ \\
\hline & & CD4 (cells/ $\mu \mathrm{L})$ & $501.54 \pm 441.90$ & $351.46 \pm 190.53$ & $1.766(p=0.10)$ \\
\hline \multirow{2}{*}{$\begin{array}{l}\text { 4.Multiple } \\
\text { Myeloma }\end{array}$} & \multirow[t]{2}{*}{7} & ANC (x $\left.10^{9} / \mathrm{L}\right)$ & $4.000 \pm 1.780$ & $2.114 \pm 0.780$ & $3.770(p=0.01)^{*}$ \\
\hline & & CD4 (cells $/ \mu \mathrm{L})$ & $566.00 \pm 439.04$ & $410.43 \pm 177.75$ & $0.993(p=0.36)$ \\
\hline \multirow{2}{*}{$\begin{array}{l}\text { 5.Colorectal } \\
\mathrm{Ca}\end{array}$} & \multirow[t]{2}{*}{6} & $\mathrm{ANC}\left(\mathrm{x} 10^{9} / \mathrm{L}\right)$ & $3.817 \pm 1.508$ & $3.250 \pm 1.060$ & $1.619(\mathrm{p}=0.17)$ \\
\hline & & CD4 (cells $/ \mu \mathrm{L})$ & $641.83 \pm 325.17$ & $374.50 \pm 189.30$ & $2.818(p=0.04)^{*}$ \\
\hline 6. Ca Cervix & \multicolumn{3}{|c|}{1} & \multicolumn{2}{|c|}{ NOT APPLICABLE } \\
\hline \multirow{2}{*}{$\begin{array}{l}\text { 7. Other } \\
\text { Cancer }\end{array}$} & \multirow[t]{2}{*}{9} & $\operatorname{ANC}\left(\times 10^{9} / \mathrm{L}\right)$ & $3.778 \pm 1.651$ & $2.711 \pm 1.657$ & $2.131(\mathrm{p}=0.07)$ \\
\hline & & CD4 (cells $/ \mu \mathrm{L})$ & $524.89 \pm 376.09$ & $324.00 \pm 180.11$ & $2.635(\mathrm{p}=0.030)^{*}$ \\
\hline
\end{tabular}

* Statistically Significant, $\mathrm{p}<0.05$

$\mathrm{STD}=$ Standard Deviation; Freq = Frequency: ANC = absolute neutrophil count

CD4 $=$ CD4 positive lymphocyte count

$\mathrm{Ca}=$ Cancer; $\mathrm{NHL}=$ Non - Hodgkin's Lymphoma

In all 36/80 (45\%) cases of breast cancer were seen. males and $1 / 36(3 \%)$ male patient. Most of the patients The patients' ages ranged from 26-69 years with a mean (58.3\%) presented with advanced disease, while 15/36 age of 48 years, and this consisted of 35/36 (97\%) fe- $\quad(41.7 \%)$ of them presented with the early stage of the disease 
Table 2: Observed Mean ANC and CD4 counts with different Cytotoxic Regimen

\begin{tabular}{|c|c|c|c|c|c|}
\hline Drug Regimen & $\begin{array}{l}\text { Frequency } \\
\text { (N) }\end{array}$ & $\begin{array}{l}\text { Parameters (Mean } \\
\text { value) }\end{array}$ & Day $0 \pm$ STD & Day $12 \pm$ STD & $\mathrm{t}$-Test (p value) \\
\hline \multirow[t]{2}{*}{\begin{tabular}{|l}
$1 .(\mathrm{C} \& A)$ \\
\end{tabular}} & \multirow[t]{2}{*}{30} & ANC & $3.757 \pm 2.431$ & $2.352 \pm 1.585$ & $3.633(\mathfrak{p}<0.001)^{*}$ \\
\hline & & CD4 & $621.70 \pm 374.33$ & $442.70 \pm 255.26$ & $5.083(\mathrm{p}<0.001)$ \\
\hline \multirow{2}{*}{\begin{tabular}{|l|} 
2. C \&A+ \\
Cisplatin
\end{tabular}} & \multirow[t]{2}{*}{4} & ANC & $3.600 \pm 0.990$ & $2.100 \pm 0.707$ & $1.250(\mathrm{p}=0.43)$ \\
\hline & & CD4 & $668.00 \pm 178.19$ & $271.50 \pm 6.36$ & $3.263(\mathrm{p}=0.19)$ \\
\hline \multirow[t]{2}{*}{ 3. CHOP } & \multirow[t]{2}{*}{6} & ANC & $2.840 \pm 1.552$ & $1.860 \pm 279.65$ & $1.850(\mathrm{p}=0.14)$ \\
\hline & & CD4 & $728.20 \pm 287.37$ & $584.00 \pm 279.65$ & $1.850(\mathrm{p}=0.14)$ \\
\hline \multirow[t]{2}{*}{ 4.C \& Epirubicin } & \multirow{2}{*}{3} & ANC & $2.700 \pm 1.697$ & $2.800 \pm 0.424$ & $-0.067(\mathrm{p}=0.96)$ \\
\hline & & CD4 & $665.50 \pm 169.00$ & $280.50 \pm 53.03$ & $2.452(\mathrm{p}=0.96)$ \\
\hline \multirow[t]{2}{*}{ 5. COPP } & \multirow[t]{2}{*}{6} & ANC & $4250 \pm 2.089$ & $4.083 \pm 3.647$ & $0.144(\mathrm{p}=0.89)$ \\
\hline & & CD4 & $378.00 \pm 189.83$ & $261.67 \pm 133.98$ & $2.828(\mathrm{p}=0.04)^{*}$ \\
\hline \multirow[t]{2}{*}{ 6. C\& A+5-FU } & \multirow[t]{2}{*}{3} & ANC & $3.880 \pm 3.705$ & $1.195 \pm 1.563$ & $0.721(\mathrm{p}=0.60)$ \\
\hline & & CD4 & $942.50 \pm 300.52$ & $623.00 \pm 42.43$ & $1.751(\mathrm{p}=0.33)$ \\
\hline \multirow[t]{2}{*}{ 7. ABVD } & \multirow[t]{2}{*}{7} & ANC & $2.950 \pm 2.765$ & $1.547 \pm 0.696$ & $1.418(\mathrm{p}=0.22)$ \\
\hline & & CD4 & $452.50 \pm 443.85$ & $352.17 \pm 48.49$ & $0.613(\mathrm{p}=0.567)$ \\
\hline \multirow[t]{2}{*}{ 8. M\&P } & \multirow[t]{2}{*}{4} & ANC & $3.167 \pm 1.914$ & $1.633 \pm 0.513$ & $1.403(\mathrm{p}=0.3)$ \\
\hline & & CD4 & $536.00 \pm 151.09$ & $503.67 \pm 176.47$ & $0.462(\mathrm{p}=0.69)$ \\
\hline \multirow[t]{2}{*}{ 9. C,Mtx \& 5-FU } & \multirow[t]{2}{*}{5} & ANC & $2.550 \pm 0.495$ & $1.850 \pm 0.919$ & $2.333(\mathrm{p}=0.26)$ \\
\hline & & CD4 & $538.50 \pm 293.45$ & $467.50 \pm 408.00$ & $0.877(\mathrm{p}=0.54)$ \\
\hline \multirow[t]{2}{*}{ 10. M,P \& T. } & \multirow[t]{2}{*}{3} & ANC & $4.100 . \pm 2.263$ & $2.100 \pm 0.707$ & $1.818(\mathrm{p}=0.32)$ \\
\hline & & CD4 & $948.50 \pm 755.90$ & $452.50 \pm 65.76$ & $0.854(\mathrm{p}=0.55)$ \\
\hline \multirow[t]{2}{*}{ 11. FCA } & \multirow[t]{2}{*}{5} & ANC & $3.750 \pm 1.863$ & $2.900 \pm 1.236$ & $2.142(\mathrm{p}=0.12)$ \\
\hline & & CD4 & $605.75 \pm 361.84$ & $304.50 \pm 89.44$ & $1.915(\mathrm{p}=0.15)$ \\
\hline \multirow[t]{2}{*}{ 12. Others } & \multirow[t]{2}{*}{4} & ANC & $4.288 \pm 2.189$ & $2.935 \pm 1.269$ & $2.973(\mathrm{p}<0.01)^{*}$ \\
\hline & & CD4 & $527.82 \pm 374.54$ & $380.29 \pm 224.36$ & $3.048(\mathrm{p}=<0.01)^{*}$ \\
\hline
\end{tabular}

*Statistically Significant, $(\mathrm{p}<0.05)$

$\mathrm{C}=$ Cyclophosphamide; $\mathrm{M}=$ Melphalan; $\mathrm{P}=$ Prednisolone; $\mathrm{Mtx}=$ Methotrexate
$\mathrm{T}=$ Thalidomide; $\mathrm{FAC}=5$-FU, Adriamcyin, Cisplatin 5 - $\mathrm{FU}=5$-Fluorouaraci

$\mathrm{C}=$ Cyclophosphamide; $\mathrm{O}=$ Oncovin (Vincristine) $; \mathrm{P}=$ Procarbazine; $\mathrm{A}=$ Adriamcy in

$\mathrm{H}=$ Hydroxodaunorubicin; $\mathrm{P}=$ Prednisolone; $\mathrm{B}=$ Bleomycin; $\mathrm{V}=$ Vinblastine; $\mathrm{D}=$ Dacarbazin

Eight $(8 / 80)(10 \%)$ of the patients had non-Hodgkins ma, of whom 4/7(57.1\%) were males and 3/7 $(42.9 \%)$ ymphoma (NHL), $6 / 8(75 \%)$ of these were males were females. Their ages ranged from 31 - 75 years, while $2 / 8(25 \%)$ were females and their ages ranged with a median age of 58 years. Majority of the patients, from 18-67 and a mean age of 39.13 years. Six (75\%) $6 / 7$ (85.7\%) presented with advanced disease (Durie of the patients presented with the early stages of the \&Salmon stage III or IIb), while only one patient had disease (stage I \& II), while $2 / 8(25 \%)$ presented with early disease. There was a total of $6 / 80$ with colorectal the later stages of the disease. ymphoma, aged 18-65 years with a mean age of 38 dian age of 46 years, and $4 / 6(66.7 \%)$ had early disease, years. Of these $9 / 13(69.2 \%)$ presented with the early while $2 / 6(33.3 \%)$ had late disease. Only one case of ca stages of the disease, while $4 / 13(30.8 \%)$ had the ad- was seen in a 48 year old woman, who had a pre-and vanced stages of the disease. Seven (53.8\%) of them post - chemotherapy ANC of $7.8 \times 10^{9} / \mathrm{L}$ and $3.9 \times$ were males while $6 / 13(46.2 \%)$ were females. $10^{9} / \mathrm{L}$ respectively, and CD4 count of 1258 cells $/ \mu \mathrm{L}$ and 805 cells $/ \mu \mathrm{L}$, respectively. For this single outcome the test for statistical significance could not be applied.

\section{Figure 1a-d: Changes in the ANC and CD4 counts noted in respondents}

Figure f

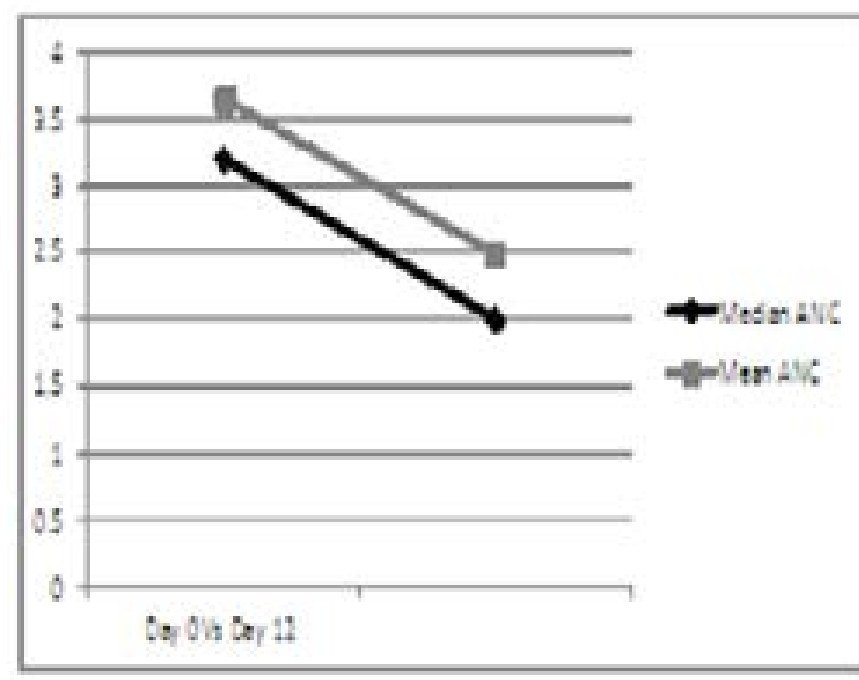

figure tc

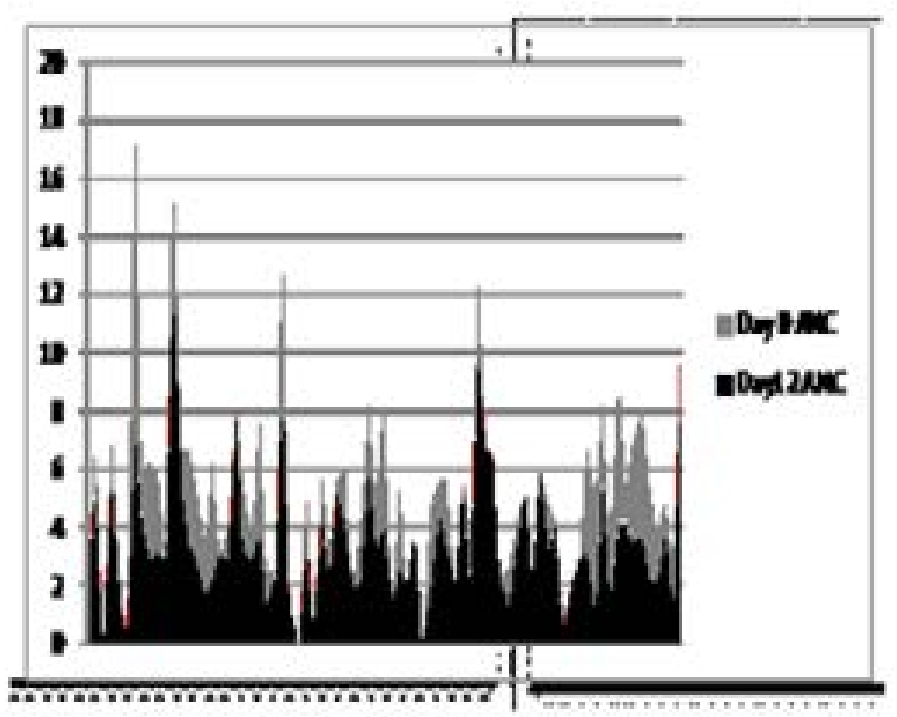

African Health Sciences Vol 15 Issue 2, June 2015
Figure fo

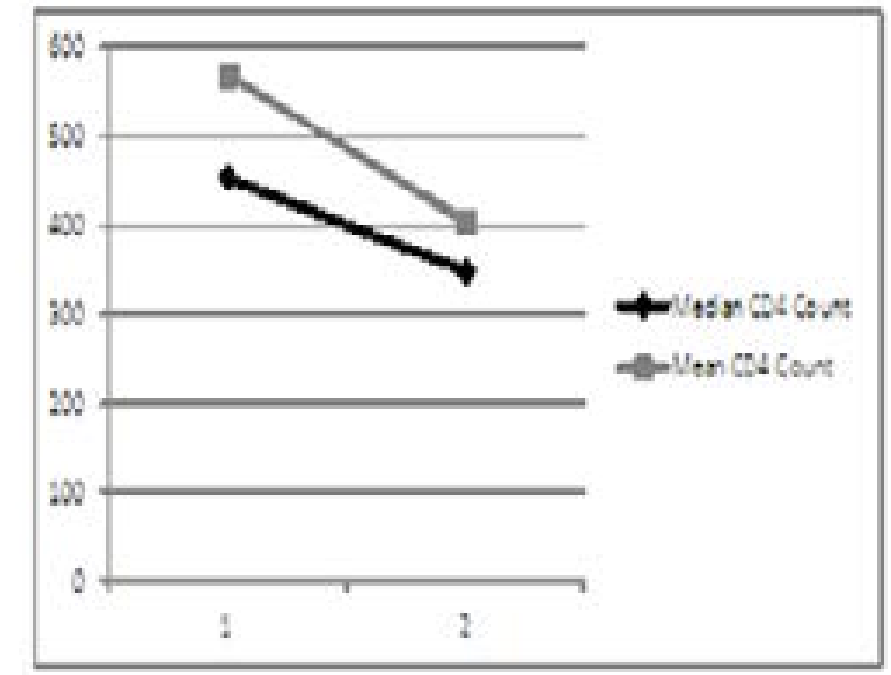

Figure id

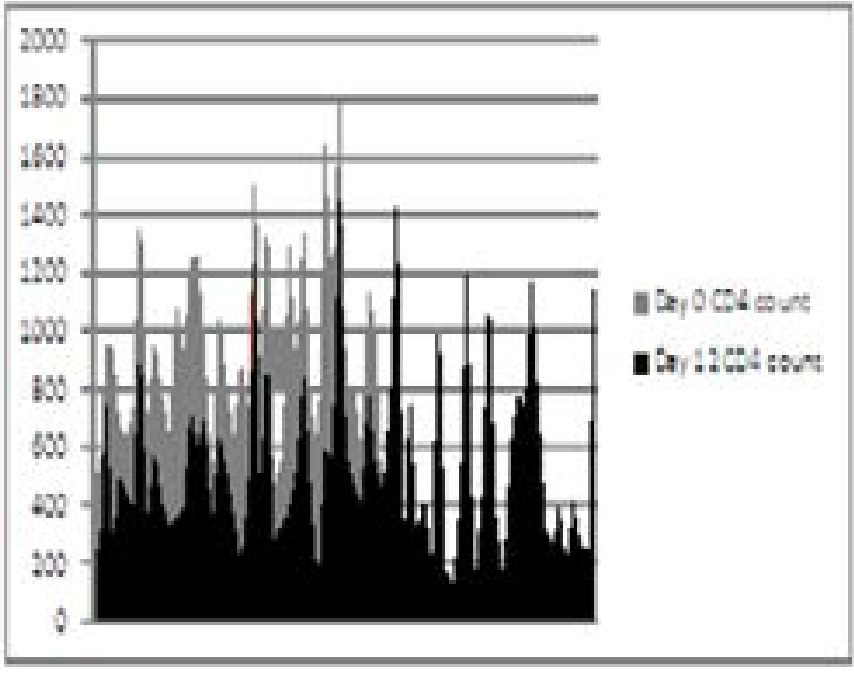


The other malignancies recorded were ovarian carci- frequently seen, each contributing less than $3 \%$ of all noma, serminomas, osteosarcoma, malignant fibrous cases seen. This category consisted of $9 / 80(11.25 \%)$ histiocytoma, liposarcoma, squamous cell carcinoma of the patients, their ages ranged from 25-72 years, with and cancers of the larynx, stomach, urinary bladder, a median age of 44 years. Five 5/9 (55.6\%) of the paand rhabdomyosarcomas. These malignancies were less tients presented with early disease, while 4/9 (44.4\%) had advanced cancers.

Figure 2: Age and gender distribution of respondents

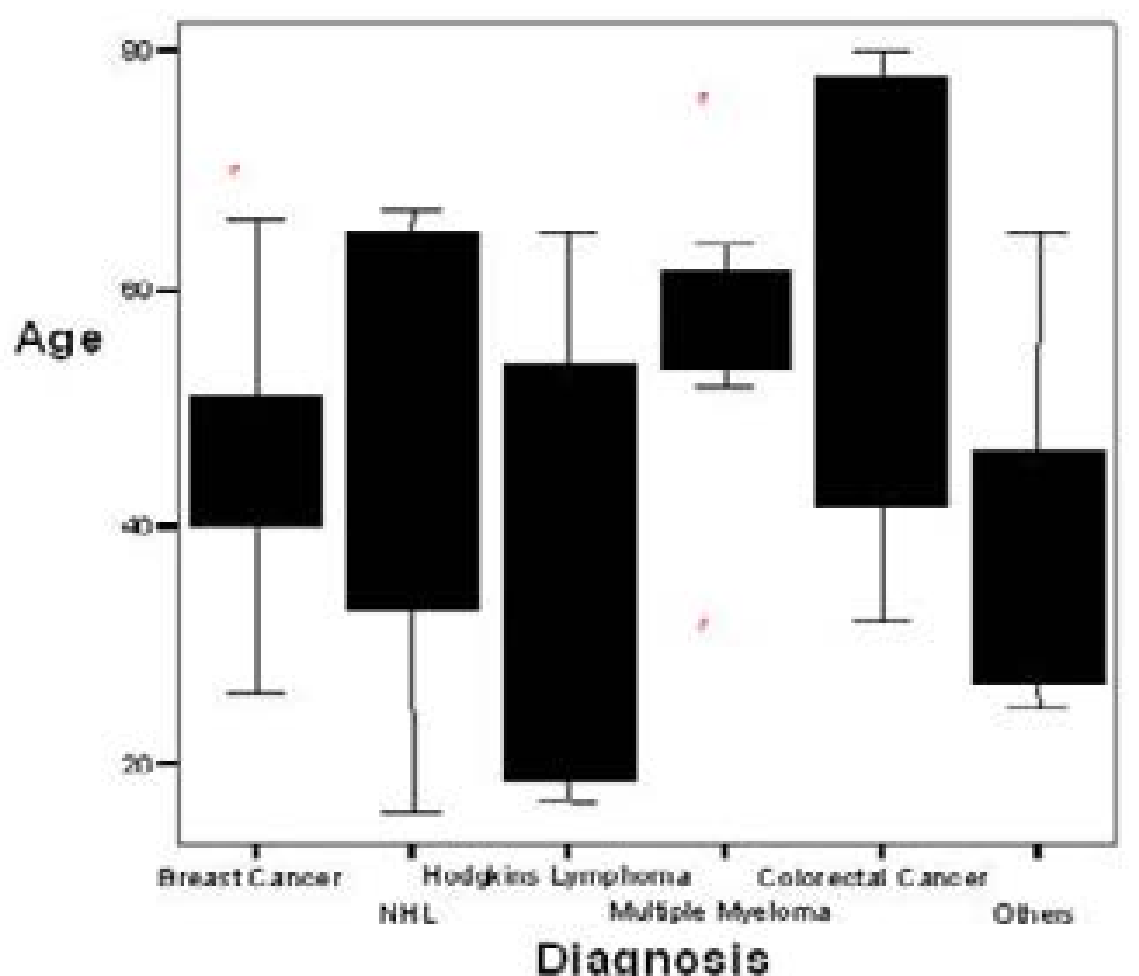

Discussion

cer patients recruited, as this has been noted to be the In this study the patients were mainly adults between 18 most prevalent cancer in most studies in adults. and 80 years, with a median age incidence of 45 years. This supports the general knowledge that malignancies can occur in any age group. It is however noteworthy that the population used in this study is not representative of the overall cancer population in adults patients, since only patients whose malignancies were amenable to chemotherapy were recruited. However a comparison of the changes observed in absolute neutrophil count to that of the CD4 lymphocyte count can still be deduced from the result of this study. Majority of the affected patients were females $(66.3 \%)$, this is similar to the data on sub-Saharan Africa from the World cancer 5 year prevalence study ${ }^{10}$, but data from the study done by Borg \& Ray- Coquard et al had more of males (56\%). This was probably due to the proportion of breast can-
Also other more common malignancies noted in other cancer prevalence studies, like cancer of the cervix and prostate were not usually treated with chemotherapy in their early stages. Non-Hodgkin's lymphoma was the third most common malignancy in this study and this is supported by findings of other studies in adult populations in Nigeria. ${ }^{10}$ About half of the patients in this study presented with early stages of their malignancies, this not supported by the finding of Borg's group in cancer patients in France, ${ }^{2}$ where more than $65 \%$ of the patients presented with advanced disease.

The mean values of neutrophil and CD4 lymphocytes recorded before and after chemotherapy in this study was found to be 3.7 and $2.5 \times 10^{9} / \mathrm{L} ; 594$ and 412 cells $\mu \mathrm{L}$, respectively which were all within the normal reference ranges for Nigerians except the day 12 CD4 lymphocyte count. The changes in these parameters from the pre-chemotherapy values were both statistically significant. This is similar to the findings of Khan et al in his study on solid tumours, ${ }^{13}$ and may be an indicator that the CD4 count is a more appropriate index of immunosuppression within the first few days post-chemotherapy.

In breast cancer patients mean absolute neutrophil counts pre-and post-chemotherapy were both with the normal reference range for Nigerians. This is similar to the results obtained in studies by Silber et al who observed a first cycle of ANC nadir of $2.1-9.2 \times 10^{9} / \mathrm{L}$, ${ }^{14}$ and another study done by Rivera et al who obtained values of $2.3-9.9 \times 10^{9} / \mathrm{L} .{ }^{15}$ Studies done in Negros in Africa had revealed lower neutrophil counts and this has been shown to be also true for black population elsewhere. ${ }^{6,7,16}$ Worthy of note also is the fact that Ezeilo deduced from his study that neutropenia in Africans was non-genetic, but this was contrary to observations by Hershman et al,of neutropenia in African American females. ${ }^{6,16}$ However the change in absolute neutrophil count in these patients was found to be significant, as had been seen in previous studies. The pre-chemotherapy mean CD4 count was within normal adult reference values, but this dropped to a significantly lower value post-chemotherapy, as has been noted in other studies.

Lymphomas have been shown to have additional immunosuppressive effects in affected patients; this ma be greater on the humoral than the cellular aspect of patients' immune system which this study is focused The change in CD4 lymphocyte count in these patients was found to be significant $(\mathrm{p}=0.043)$. Most of the patients in this group received cyclophosphamide, hydroxodaunorubicin, oncovin and prednisolone (CHOP) chemotherapy, which contained cyclophosphamide and daunorubicin. In the study done by Mackall et al sionificant depreciation of both the ANC and CD4 counts were observed, however the NHL patients in this study received higher doses of chemotherapy (cyclophosphamide $1.6 \mathrm{~g} / \mathrm{m}^{2}$, doxorubicin $40 \mathrm{mg} / \mathrm{m}^{2}$ methotrexate $6.72 \mathrm{~g} / \mathrm{m}^{2}$ and vincristine $\left.1.5 \mathrm{mg} / \mathrm{m}^{2}\right)$.

Though in these studies a low baseline CD4 count was recorded, which was not supported by our study. However we noted again that amongst patients with NHL the $\mathrm{CD} 4$ count was a better and more suitable marker of immunosuppression than the ANC, showing a significant change of $\mathrm{p}<0.05$. Individuals with Hodgkin's lymphoma in this study had normal baseline mean CD4 counts as previous studies had shown. This was more in the patient group who received cyclophosphamide, oncovin, procarbazine, prednisolone(COPP), and lesser with the patients who were given adriamycin, bleomycin, vinblastine and darcabazine (ABVD). Previous reports show that ABVD is less toxic to the gonads, and thus cause less infertility than COPP, findings of this study however suggests that it may actually be less immunotoxic. This may be due to the 14 day treatment with oral procarbazine compared to the single parenterl dose of dacarbazine.

In patients diagnosed with multiple myeloma, only the change in ANC was significant and the day 12 ANC was lower than the Caucasian reference values, but still within the normal reference range in Nigerians. The mean pre-chemotherapy ANC and CD4 counts were within normal range, this is similar to the findings by Borg's group, who recorded a median CD4 counts of 650 cells $/ \mu \mathrm{L}$ and ANC of $5.1 \times 10^{9} / \mathrm{L} .{ }^{2}$ However in this study melphalan -based combinations were used for majority of the patients, while in Borg study other dexamethasone-base combinations were preferred. Though similar outcomes were recorded in both studies, it must be noted that in Borgs study some of the patients had been exposed to previous chemotherapeutic treatment and the pre-chemotherapy values were assessed on day 5 of the cycle. 
Only one patient with cervical cancer was recruited into in chemotherapeutic agents used. Single agent cancer this group, this low rate may be attributable to the pref- chemotherapy is rarely practiced and ethical issues limit erence for other modes of treatment, mostly radiother- studies of this kind with respect to isolating the individapy and surgery. Use of cytotoxic chemotherapeutic ual effect of these drugs.

agents is usually reserved for the very advanced cases;

the outcome from this group was therefore too few to The patients who received cyclophosphamide and adribe analyzed.

The pre-chemotherapy mean CD4 count in patients with other malignancies was the second lowest, after Hodgkin's lymphoma, also the change in this parameter was found to be significant. The individuals in this group had a wide variety of malignancies viz; osteosarcoma, liposarcoma, squamous cell carcinoma, histiocytoma, seminoma, as well as cancer of the larynx, ovaries, stomach and urinary bladder. However the change in blood parameters within each patient, irrespective of the differences between individual patients (in term of diagnosis of chemotherapy regimen used) is still worthy indicator of the degree of immunosuppression in each group of patients. These patients also received a wider variety of drugs compared to other groups; though both parameters were depressed as expected the CD4 count proved to be more sensitive of the immunosuppressive effect of these drugs.

The CD4 lymphocyte was generally was found to besignificantly reduced in more patient groups than the $\mathrm{ANC}$, and this may be an indication of the suitability of this parameter.

Effects of different chemotherapeutic agents on ANC and CD4 Count

The patients in this study were exposed to a wide range of cytotoxic drugs based on their various diagnoses. However some of these individuals with similar diagnosis in some instances received different chemotherapeutic regimen. The differences in regimen given were based on the stage of the disease or its aggressiveness, age of the patient, presence of other co-morbidities, or performance status, as well as the individual biases of the managing team. This has offered an, albeit less than ideal, opportunity to compare the extent of immunosuppression caused by these various combinations, and perhaps an opportunity to identify some "worse offending" drugs or combinations. However as previously noted the change in each of these immunological parameters within each individual still remains a valid means of comparison irrespective of the differences mycin showed changes in both their mean ANC and CD4 counts, however only the ANC was significantly reduced. The dose of adriamycin in this regimen was $50 \mathrm{mg} / \mathrm{m}^{2}$, as opposed to the dose in ABVD which is $25 \mathrm{mg} / \mathrm{m}^{2}$, which seemed to cause less immuno-toxicity. This is similar to the findings of Borg et al where the doses of some of the drugs rather than the individual grents themselves were found to be the causative factor. Doses of Adriamycin in excess of $90 \mathrm{mg} / \mathrm{m}^{2}$ or cyclophosphamide $\geq 1 \mathrm{~g} / \mathrm{m}^{2}$ per course have been implicated as a cause of immunosuppression. ${ }^{15}$

Other chemotherapeutic agents used were basically for less frequent malignancies, advanced or aggressive disease. These combinations are generally thought to be as toxic as they are potent and it is therefore not surprising they sionificantly lower the ANC and CD4 counts as found in this study.

\section{Conclusion}

This study confirms that anti-cancer chemotherapy causes significant depletion of neutrophils as well as CD4 lymphocytes in adults with malignancies. However we observed that CD4 lymphocyte count are depleted more significantly, than ANC in patients diagnosed with several malignancies. Also COPP seems to cause more significant $\mathrm{CD} 4$ depletion than other combinations used to treat lymphoma. This may be of more importance in people of Negroid descent with a lowe baseline ANC. It may be necessary to embark on a more elaborate and extensive study in order to determine the authenticity of these findings in larger patient group.

The authors declare no conflict of interest.

\section{References}

1. Sharma A, Lokeshwar N: Febrile neutropenia in haematological malignancies. J Postgrad Med 2005;51 Suppl :S42-S48

. Borg C, Ray-Coquard I, Philip I, Clapisson G, Ben-

\section{Conflict of interest}

driss-Vermare N, Menetrier-Caux C,et al: CD4 lymphopenia as a risk factor for febrile neutropenia and early death after cytotoxic chemotherapy in adult patients with cancer. Cancer 2004;101:2675-2680.

3. Mackall CL: T-cell immunodeficiency following cytotoxic antineoplastic therapy: a review. Stem Cells 2000;18:10-18.

4. Ngowi BJ, Mfinanga SG, Bruun JN, Morkve O Immunohaematological reference values in human immunodeficiency virus-negative adolescent and adults in rural northern Tanzania. BMC Infect Dis 2009;9:1.

5. Njoku MO, Sirisena ND, Idoko JA, Jelpe D: CD4+

T-lymphocyte counts in patients with human immunodeficiency virus type 1 (HIV-1) and healthy population in Jos, Nigeria. Niger Postgrad Med J 2003;10:135-139. 6. Ezeilo GC: White Blood Cells; Textbook of physiology. New Delhi, Oxford University Press, 2004, p 93.

7. Ukaejiofor EO ISWSAEIA: Normal Haematological values in adult Nigerians. Nigerian Medical Journal, 1979;9:117-119.

8. O'Brien SN, Blijlevens NM, Mahfouz TH, Anaissie EJ: Infections in patients with hematological cancer: recent developments. Hematology Am Soc Hematol Educ Program 2003;438-472

9. Rolston KV BG: Infections in patients with cancer, Cancer Medicine. Ontario, BC Decker Inc., 2002, pp $335-370$
10. Durosinmi MA.: A design Handbook of Haemao-Oncology Chemotherapy for Medical students \& Doctors. ed 2nd, IIupeju Lagos: Amkra Books, 2008. 11. Ojo OS: Cancer in Africa. IARC 2003;153:94.

12. Adelusola KA: African Cancer Prevalence. C Afr J Med 1995;41:332.

13. Khan S, Dhadda A, Fyfe D, Sundar S: Impact of neutropenia on delivering planned chemotherapy for solid tumours. Eur J Cancer Care (Engl) 2008;17:19-25. 14. Silber JH, Fridman M, DiPaola RS, Erder MH, Pauly MV, Fox KR: First-cycle blood counts and subsequent neutropenia, dose reduction, or delay in early-stage breast cancer therapy. J Clin Oncol 1998;16:23922400

5. Rivera E, Haim EM, Fridman M, Frye D, Hortobagyi GN: First-cycle absolute neutrophil count can be used to improve chemotherapy-dose delivery and reduce the risk of febrile neutropenia in patients receiving adjuvant therapy: a validation study. Breast Cancer Res 2003;5:R114-R120

16. Hershman D, Weinberg M, Rosner Z, Alexis K, Tiersten A, Grann VR et al: Ethnic neutropenia and treatment delay in African American women undergoing chemotherapy for early-stage breast cancer. J Nat Cancer Inst 2003;95:1545-1548. 